\title{
Impact of Information and Communication Technology (ICT) on construction projects
}

\author{
Aimie Rimmington \\ Construction Management \\ in the School of Architecture \\ Design and the Built \\ Environment, Nottingham \\ Trent University, \\ aimie.rimmington@ntu.ac.uk
}

\author{
Dr. Graham Dickens \\ Construction Management \\ in the School of Architecture \\ Design and the Built \\ Environment, Nottingham \\ Trent University, \\ graham.dickenso2@ntu.ac.uk
}

Dr. Christine Pasquire

Construction Management in the School of Architecture Design and the Built Environment, Nottingham Trent University,

christine.pasquire@ntu.ac.uk
DOI 10.5592/otmcj.2015.3.4

Research paper

\section{Keywords}

ICT; Project teams;

Construction;

Communication;

Organisations
THE CHANG ING FACE OF CONSTRUCTION PROJECTS HAS RESULTED IN A MOVEMENT TOWARDS THE USE OF TECHNOLOGY AS A PRIMARY MEANS OF COMMUNICATION. THE CONSEQUENCES OF THIS RISE IN THE USE OF INFORMATION AND COMMUNICATION TECHNOLOGY (ICT) IS A LOSS OF INTERPERSONAL COMMUNICATION SKILLS. A number of resulting issues within the human - electronic and human - human interfaces are identified in an attempt to define the efficiency of communication in projects. The research shows how ICT effects the social environment of construction project teams and the project outcome. The study seeks to confirm the need for further work in order to develop new forms of communication protocols and behaviour. An initial literature review was undertaken to develop a theoretical review of the impacts of ICT on construction project teams. This review identified a number of issues that were then tested in the field through an observation and two verification interviews. The research confirms the existence of tensions and conflicts in the human - electronic and human - human communication interfaces within the studies environment. It is proposed that the increasing use of ICT occur at the expense of soft system communication. The principal impact of this is a form of 'human distraction' which adversely affects the performance of project teams. There is limited theory exploring these issues that suggests the problems identified are not well understood and consequently indicates a gap in knowledge. 


\section{INTRODUCTION}

The cultural context of construction projects has changed in recent years creating a more complex business environment. One reason behind this is the rapid development of communication technologies. With the increasing need to have immediate information and flexible working practices in a global market, information transfer tends to be electronic. This enables increased volume of information transfer dependent on the time zone. These information and communication technologies (ICT) have encouraged geographical dispersion and a retreat from face to face contact with more asynchronous communication (Hoch and Kozlowski, 2014). This shift from the traditional people-centred organisation has been shown by numerous scholars to house difficulties (Avolio et al., 2000; Bell \& Kozlowski, 2002; Purvanova \& Bono, 2009). The construction sector is no different from any other in this regard. Fryer (2004, p.62) believes 'poor communication has long been a problem in the construction industry with part of the trouble being the way the industry is organised'.

Information and communication technology (ICT) is defined and discussed differently in construction writings but Kraemer and Daniziger, (1990, p.593-594) define the communication element of technology as 'the actual hardware employed to perform a basic information processing task'. Emmitt and Gorse (2003) also take the view that communication within organisations and between them is concerned with the exchange of information and the management of it. Onyegiri et al (2001, p.462) have summarised the different interpretations of ICT into a flow diagram in their work. Based on this flow diagram, Figure 1 shows the flow of information from a form of communication. There is a need to distinguish between 'information technology' and 'communication technology' since information technology is essential in construction for the storage of information but its use

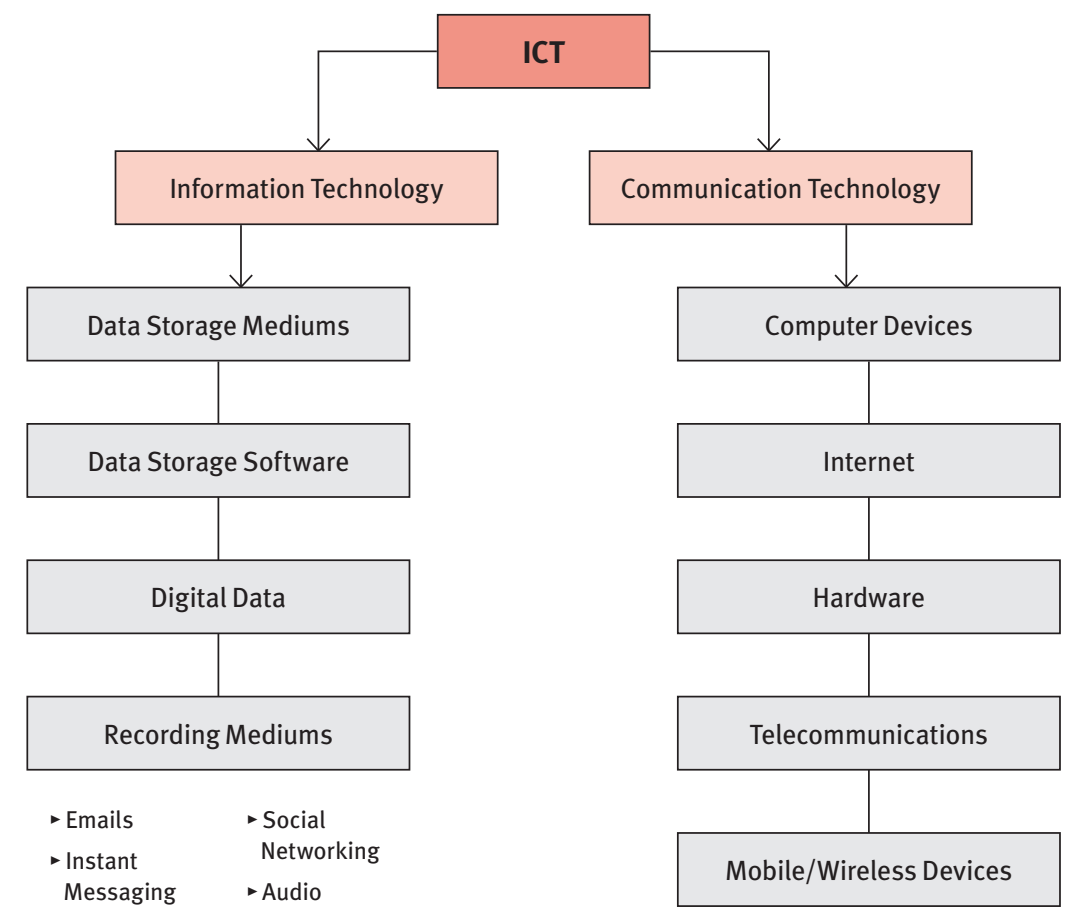

Figure 1: Typical flow of information through a medium of communication.

does not necessarily mean communication has to take place.

In the construction industry today there is a growing trend for ICT to be used from conception to completion of a project process (Onyegiri et al, 2011) with the development of computers, computer software (e.g. Computer Aided Design (CAD) and Building Information Modelling (BIM), internet, mobile phones and so on. This does not, however, necessarily improve communication as messages and data are still open to interpretation that is influenced by distraction and noise. The term 'distraction' has been used in this context to refer to how ICT creates a diversion or prevention from what one should be concentrating on or doing (Oxford Dictionaries, 2015) which subsequently has an impact on role and project performance. The overuse of ICT in the replacement of the human to human interface can be classed as a distraction (or noise). 'Factors which detract from efficient communication are termed noise' thus ICT is a noise creating distractions in the design and management of construction projects (Newcombe et al, 1990, p.127) and impacting the 'performance' of project teams.

For the purpose of this study, 'performance' is defined as the behaviours, skills, culture and background of employees and teams that support and contribute to the success of an organisation (Dane, 2011; Parker, 2000; Arvey and Murphy, 1998). Pulakos et al (2012, p.7) outline job performance as 'synonymous with behaviour' whilst effectiveness houses many factors - one of these is 'performance' (Bernold, 2010). Bernold (2010, p.24) identifies team performance as that which is influenced by 'the roles that individual members play, their relationship to eachother, the differences in task and social influences and the behaviour of individuals within the group norms'.

Construction project organisations 
rely upon communication, which according to Dainty et al $(2006$, p.3) is 'the sharing of meaning to reach mutual understanding and gain a response'. The sharing of meaning is dependent on the accuracy of the information followed closely by having the appropriate communication procedures (Thomas et al., 1998). Communication may be categorised as written communication, face to face verbal communication and electronic communication, (Shohet and Frydman, 2003) and this can be divided further into formal and informal (Parker, 1980; Atkin et al, 1994). Messages are readily sent within an office environment (even from mobiles), however, testing of understanding is seldom carried out. It is therefore necessary to be aware of how the recipient prefers the message to be conveyed and encoded so that it is easily decoded and conveyed (Dainty, Moore and Murray, 2006). Encoding and decoding a message is not just dependent upon the sender and the recipient, noise has a big impact in distorting the message (Dewatripont et al, 2005; Shannon and Weaver, 1949). Noise can come from many sources such as, the transmitting vehicle, culture, education, professional bodies, mode of encoding and decoding and so on. Nonetheless, the main 'noise' focus here is ICT and the way in which it is organised in project teams and its distractions and barriers to effective communication.

Written and electronic communication omit the subliminal messages given by body language (facial expression) thus restricting the effectiveness of communication. Spoken communication, accounts for only forty eight percent of construction communication (Shohet and Frydman 2003) even though face to face communication is the most effective method of transmitting and understanding a message (Emmitt and Gorse, 2007) especially as physical presence encourages trust (Lester, 2007).

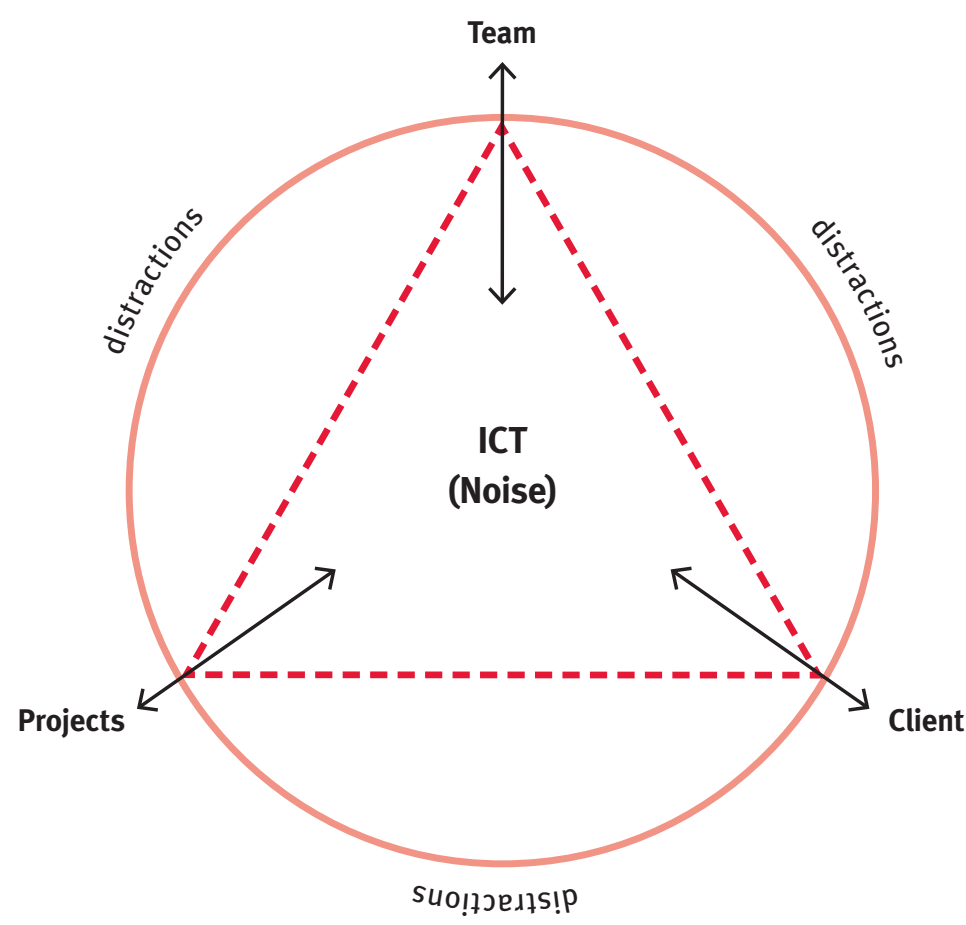

Figure 2: Information communication technology (ICT) as the core of a construction business.

The Silo effect in communication developed after the industrial revolution due to the fragmentation of the construction industry (Emmitt, 2010) and grew as a result of the onset (and increase) of ICT in the 1970 (Dainty, Moore and Murray, 2006). The compartmentalisation of professionals in the industry is also exacerbated due to the rise and diversity of specialisms (Fellows and Lui, 2012; Dainty, Moore and Murray, 2006). For example, each professional body acts on behalf of each specialism seeking 'to protect the interests of their members by laying claim to a particular knowledge 'territory' that differentiates them from others' (Dainty, Moore and Murray, 2006, p.93). However, the overall effect of ICT (and the subsequent rise in specialisms) is the distraction from (and barrier to) communication (Dainty, Moore and Murray, 2006).

There are therefore a number of gaps to be explored and these have framed this study into an examination of the distractions caused by the way ICT is organised (and accordingly used) in the management of construction projects. Additionally, the study seeks to identify specific impacts of these distractions. Figure 2 is a conceptual representation of the central theme of this paper, placing emphasis on how ICT is the core of communication on a construction project. The primary research intends to provide some empirical evidence to determine some of the impacts and effects of this on the performance of individuals and teams involved in construction project delivery.

In order to explore this impact it is necessary to review communication in construction project organisations and their ICT strategies, virtual team working, distractions and inefficiencies caused by the use of ICT and any cultural differences.

What is communication?

Construction project organisations rely upon communication, which according to Dainty et al (2006, p.3) is 'the sharing of meaning to reach mutual understanding and gain a response'. 
The sharing of meaning is dependent on the accuracy of the information followed closely by having the appropriate communication procedures (Thomas et al., 1998). Communication may be categorised as written communication, face to face verbal communication and electronic communication, (Shohet and Frydman, 2003) and this can be divided further into formal and informal (Parker, 1980; Atkin et al, 1994). Messages are readily sent within an office environment (even from mobiles); however, testing of understanding is seldom carried out. It is therefore necessary to be aware of how the recipient prefers the message to be conveyed and encoded so that it is easily decoded and conveyed (Dainty, Moore and Murray, 2006). Encoding and decoding a message is not just dependent upon the sender and the recipient, noise has a big impact in distorting the message (Dewatripont et al, 2005; Shannon and Weaver, 1949). Noise can come from many sources such as, the transmitting ve- hicle, culture, education, professional bodies, mode of encoding and decoding and so on. Nonetheless, the main 'noise' focus here is ICT and the way in which it is organised in project teams and its distractions and barriers to effective communication.

Written and electronic communication omit the subliminal messages given by body language (facial expression) thus restricting the effectiveness of communication. Spoken communication, accounts for only forty eight percent of construction communication (Shohet and Frydman 2003) even though face to face communication is the most effective method of transmitting and understanding a message (Emmitt and Gorse, 2007) especially as physical presence encourages trust (Lester, 2007).

The Silo effect in communication developed after the industrial revolution due to the fragmentation of the construction industry (Emmitt, 2010) and grew as a result of the onset (and increase) of ICT in the 1970 (Dainty,
Moore and Murray, 2006). The compartmentalisation of professionals in the industry is also exacerbated due to the rise and diversity of specialisms (Fellows and Lui, 2012; Dainty, Moore and Murray, 2006). For example, each professional body acts on behalf of each specialism seeking 'to protect the interests of their members by laying claim to a particular knowledge 'territory' that differentiates them from others' (Dainty, Moore and Murray, 2006, p.93). However, the overall effect of ICT (and the subsequent rise in specialisms) is the distraction from (and barrier to) communication (Dainty, Moore and Murray, 2006).

\section{Research Design}

The purpose of this research is to explore the impact of information and comm,unication technology (ICT) on construction projects. The review of appropriate secondary data provides the theoretical position of the work (Bryman, 2008) and determines what

\section{Questions}

1. How is ICT affecting the efficiency of projects and/or project organisations. What are the impacts of its use?

2. Is intranet or extranet preferred for working practices on a project or other none ICT-based structure and why?

3. Are there any obvious distractions (or noise) in project organisations from ICT adoption and use and is job performance affected?

4. Is there a noticeable cultural and sex difference with the use of ICT between older and younger generations in project organisations?

5. Is it the way ICT is organised that is negatively impacting construction projects (or organisational performance) or the general overuse of ICT?

\section{Discussion}

This question aimed to allow for a wide range of responses, to remove bias, to validate the primary investigation and to analyse against the secondary research.

With ICT providing less time consuming ways to communicate and share information, construction companies are under increasing pressure to keep up to date with such technology. As a result, this question aimed to decipher whether keeping up to date with technology advancements is beneficial or not for working practices and projects.

This question aimed to discover whether, from the development of the previous questions, ICT is actually a distraction within the construction environment and/or whether ICT has an effect on people's performances.

It is clear outside of the workplace that ICT is vast amongst the younger generations in particular. Therefore, this question aimed to determine whether this was the case within the workplace and any impacts.

Once an awareness of the research was created following the previous questions (1-4), it was appropriate to determine whether it's the poor organisation of ICT that is effecting communication or its overuse due to its societal development and focus.

Table 1: Broad research questions. 
primary data should be collected. The secondary data is further used in the discussion of the empirical findings to provide a rich picture of the issues. To obtain some unique findings to substantiate the secondary research and reinforce the literature review, one observation of a typical UK construction office environment with two semi-structured interviews with project directors from two large UK national construction companies were undertaken. Overall, the underlying epistemology for this research is that of interpretivism because it allows for qualitative methodology and theoretical flexibility which supports studies on the complexity of social environments (Tuli, 2011) such as an office.

Five broad questions are posed to drive the research providing a basic guide for the semi-structured interviews and informing the office observation. These questions (Table 1) were based on the literature review and triangulated to draw specific results (Fellows and Liu, 2008) as well as to induce deeper discussion (Naoum, 2013):

\section{Primary Research}

The office of a small main contractor housing approximately nine construction personnel was observed, with permission from the company owners. Gray (2013, p.413) defines observations meticulously in one sentence 'Observation is a complex combination of sensation and perception, through which we develop schemas, the mental structures we use to organise and simplify our knowledge of the world around us'. The observation was passive with no direct communication with the office personnel and no personal information was required or recorded in line with ethical guidelines. The researcher behaved as a client representative visiting the company owners - of whom there were two. Sporadic conversation with these owners took place but no form of in-

\begin{tabular}{|c|c|c|c|}
\hline Sex & $\begin{array}{l}\text { Approxi- } \\
\text { mate age }\end{array}$ & Professional Role & $\begin{array}{l}\text { Experience in } \\
\text { Construction }\end{array}$ \\
\hline Female & $30-40$ & Personal Assistant & $20+$ years \\
\hline Female & $20-30$ & Architectural Services & $10+$ years \\
\hline Female & $20-30$ & Project Manager & $3+$ years \\
\hline Female & $30-40$ & Accounts Manager & $15+$ years \\
\hline Male & $30-40$ & Contracts Manager & $15+$ years \\
\hline Male & $50-60$ & Main Contractor/Builder & 35 years \\
\hline Male & $60-70$ & Main Contractor/Builder & $40+$ years \\
\hline Male & $20-30$ & Quantity Surveyor & $2+$ years \\
\hline
\end{tabular}

Table 2: Observation sample.

terview. The employees appeared to be oblivious to the observation taking place and proceeded with their tasks. The company employs eight people and all were present in the office at the time of the observation. These personnel are listed in Table 2 along with basic details collected from the company owners.

Additionally, two semi-structured interviews were undertaken with interviewees who worked for large, well known UK construction companies, both were male - one a Contracts Manager and the other a Quantity Surveyor - and both were highly experienced in construction (approximately $30+$ years each). The interviews took place within each employee's own workplace environment to reduce any external influences.

\section{Limitations}

The research provides a snapshot of aspects of current practice through a single observation within a UK construction SME company. This observation is supplemented by interviews from senior personnel from two large construction companies but the total sample is too small to provide generalised results.

\section{Results and Discussion}

\section{Question 1: The effect on efficiency when using ICT in Project Organisations}

In modern organisations it has become accepted practice for managers to receive reports and feedback in order to develop strategy and maintain the competitive nature of the business (Seifert and Yukl, 2010). This function has become disconnected from the operational activities in the belief that managers and leaders cannot be directly involved in the whole of the organisation (or company) themselves making the use of electronic methods increasingly attractive. Management evolved with the growth of formal organisations, but leadership is one of the oldest and most natural relationships in society (Fryer, 2004, p.48). Management is established as 'ensuring effective and efficient operations' whereas leadership is defined as 'direction setting' (Fryer, 2004, p.48). Managers are selected whilst leaders should materialise during the life of organisations through being interactive with their team. However, technology advances have been considered as a substitute to face to face commu- 
nication (Blume, Baldwin and Ryan, 2011; Pierce, 2009) with advances such as emailing, instant messaging and virtual team working disregarding conversation skills. Such asynchronous communication removes the expression of body language, atmosphere, environment and organisational processes and thus lacks engagement, understanding, learning and team building and support. Day et al (2014, p.68) established that expert leaders are influenced by 'understanding the situation and collaborating with others' yet an 'understanding' can only be gained through social constructs. Understanding has been shown to be a social aspect integral to lean construction both through active measures such as collaborative planning (Last Planner ${ }^{\circledR}$ System) and passive systems such as visual management that speaks directly to social cognitive measures (Pasquire, 2012 \& Pasquire \& Court, 2013) This was confirmed by the interviewees who believe that whilst the use of synchronous technology improves efficiency, asynchronous technology does not. They felt this was primarily because asynchronous technology did not enable understanding to be tested; this was a concern because the results of inadequate understanding do not materialise until a later time.

Belbin (1999) in particular identifies the different characteristics of the individuals within a team and identifies that there needs to be a balance of these different characteristics to make the team effective. Research concerning desirable management qualities are plentiful but one of these qualities (or characteristics) of importance to this research is emotional intelligence (EQ). Emotional intelligence is comprised of four parts equally divided into 'self' or 'others' (Slocum, 2008). Two traits understood to be essential for the management of 'others' party to a project are 'social awareness' and 'social skill'. Socially aware managers are able to distinguish 'others' moods and feelings face on and unaided (Kees and Whichard, 2006). All parties to a construction project or organisation require social skills to be able to build positive mutual relationships and connections whilst effectively doing their job. These skills include thoughtfulness, understanding and the ability to deal with complex situations and people and manage the complex network of communication. In the fragmented construction project environment, construction professionals should be aware that each form of communication with each person is relatively unique and so their social skills and awareness will play a key role in judging the situation. It is further proposed that the success of construction organisations is dependent on 'workplace democracy' which involves 'breaking down barriers, sharing information, using a collaborative approach to problem solving, and an orientation toward continuous learning and improvement' (Cascio, 1995, p.930). However, during the observation all employees stay quietly at their computers with little interaction. Problem solving only took place in person when prompted by the two company owners.

For individuals to have a strong effect on the performance of a project by performing better themselves, Thamhain (2013, p.152) found that there are a range of factors that influence these individuals, some of which include 'effective communications among team members and support units across organisational lines, good team spirit, mutual trust and respect, low interpersonal conflict' and so on. These findings promote in person communication yet the development, adoption and use of ICT does not guarantee these ideals occur or will be successful or that group performance will be more robust (Wu et al, 2005). The reliance on electronic means for reporting and feedback (such as KPI's and major Contracts) is coming into question as changing practice sees leaders of organisations demanding social interaction with their teams (Day, 2001) (particularly when a problem occurs) and turn to 'Gemba walks'(Samudio et al, 2011) to help achieve this. A Gemba walk requires the manager to 'go see for themselves' by visiting the physical place of work and talking to the people involved to help resolve problems. The social interaction achieved increases the performance of teams and improves the integration of communication (Samudio, Alves and Chambers, 2011). Denning (2013, p.10) highlights that communication should be more 'conversation' focussed rather than 'command' focussed. The development and sustainability of a complex social network relies upon the soft approaches to enable the required interaction to take place within and on behalf of the workplace. This was confirmed by the interviews that showed the company directors felt passionate about sharing information through face to face or verbal contact prior to electronic information exchange taking place. It was felt this allowed for the acquisition of understanding and knowledge acquisition but nethertheless, it rarely happens this way.

The huge reduction storage space requirements generated by electronic information are a powerful driver of its growing use in project organisations. 'This is not saying that the project is more efficient as there is a tendency to over include people causing them to incur time, that they may not with the more rational working practices' (Interviewee 1,2015$)$. It was clear from both the observation and interviews that electronic information is more readily accessed so this does improve the efficiency and speed of response in information accessing whilst the use of compartmentalised storage improves the administration of the project. Interestingly, when projects 
start going wrong, project teams fall back into face to face working i.e. the interactive in person collaborative approach. The findings from the interviews revealed that face to face communication is still perceived by many to be the most effective way of communicating, but electronic information is seen to be the most convenient as the information can be accessed at any time and from anywhere. There is also a tendency for senders to use this method as a means of passing the burden of responsibility (of understanding to the recipient).

Ultimately, project communication is complex in the construction environment without technology but with it, the complexity is increased particularly when communicating virtually (Peters and Manz, 2007).

Virtual team working is defined slightly differently amongst scholars but commonly it purports connecting people to accomplish a goal through the use of communication technologies as a result of the individuals of a group being geographically dispersed (rather than fairly local) (Townsend et al, 1998; Cohen and Mankin, 1999; Igbaria, 1999; Yager, 1997). It is rare for virtual teams to meet or interact face to face (Jarvenpaa and Leidner, 1999; Maznevski and Chudoba, 2000; Townsend et al., 1998), as the principal means of communicating is through computer-generated simulation so there is no need for team members to be together. However, face to face meetings are not precluded. Curseu et al (2008, p.629) and Furst et al (1999) assert that virtual teams can be 'socio-technical systems' with greater mutual reliance amongst one another."Communication among global virtual teams may be extremely difficult to manage and less effective than more traditional settings, and problems may also be magnified by disparity among technology infrastructures, as well as differences in technology proficiency among team
members"(Kayworth, 2000 p.184). Verburg (2013) found that virtual teams that had processes that increased the levels of mutual support, member effort, work coordination, balance of member contributions and task-related communications were able to consistently outperform other teams with lower levels. LaFasto and Larson (2001, p.181) consider that regular face to face meetings are, however, important for virtual teams: "For a group of managers spread around the world, ensuring adequate face time might mean meeting together every quarter to calibrate major activities, explore common challenges, and confirm relationships". The observation evidenced no use of virtual working and the company owners revealed that they had little experience with it. The interviewees revealed that during the recession that technology interface increased through the likes of video conferencing as firms were trying to reduce the cost of travel and meeting expenses. This attitude is still progressing even without a recession reducing face to face contact and informal interaction. The interviewees believed that the informality is required to create better understanding between individuals and overall team efficiency.

Virtuality of teams is not a distinct but a dimensional attribute, (Kirkman et al., 2004), where both geographical and temporal distances affect communication (Townsend et al. 1998; Lipnack and Stamps 2000). Townsend et al (1998) believe that members of virtual project teams should be more skilled when working with other team members due to a changed and more diverse culture and the lack of in person contact. Whilst task design impacts on the suitability for levels of virtuality (Konradt \& Hertel, 2002), communication is a key skill in construction projects (Dainty et al. 2006) and this is even more so in virtual teams. Verburg (2013) found that the task-related processes were the most critical for the performance of dispersed teams, with these processes needing to be mutually supportive specifically, for task-related communications. Verburg (2013) stressed that the quality of task-related processes appears to be a significant factor in determining whether dispersion becomes a liability or an opportunity for virtual collaborative efforts, although Davis et al (2003) identified that leadership style affects group processes.

\section{Question 2: ICT Strategies' in}

Organisations

Communication always occurs in a context (Littlejohn et al, 1992), which influences understanding as well as the types of messaging and systems used. This does not mean that the information transferred is correct as an individual's perceptions are influences and distortions in the message (Cohen J and Basu K, 1987). This distortion is independent of the way in which the ICT is configured and communication is dealt with. Frankovich (1998) identifies four different formats of technology management (illustrated in Table 3) although the selection will depend on the organisational strategy.

When these organisational strategies were tested primarily the interviewees expressed a preference for the intranet rather than the extranet. However, there was agreement that a system was needed (be it intranet or extranet) that provided a clear distinction between the project work and ordinary business activities. Both interviewees currently use an intranet and extranet. An intranet was preferred by the owners of the company observed because information is more readily available with understood user-protocols in place but overall, an accessible hard drive system that the entire company shared was favoured and used. In terms of the 'organisational strategy', it was found that the 


\begin{tabular}{|l|l|}
\hline $\begin{array}{c}\text { Organisational } \\
\text { Strategy }\end{array}$ & \multicolumn{1}{c|}{ Examples } \\
\hline $\begin{array}{l}\text { Centralised: strong } \\
\text { control from head- } \\
\text { quarters }\end{array}$ & $\begin{array}{l}\text { Project management or senior management will } \\
\text { maintain responsibilities and powers (opposite of } \\
\text { decentralised organisation). }\end{array}$ \\
\hline $\begin{array}{l}\text { Replicated: identical } \\
\text { country system }\end{array}$ & $\begin{array}{l}\text { A replication of information shared nationally } \\
\text { amongst teams using software such as the extranet } \\
\text { and intranet. }\end{array}$ \\
\hline $\begin{array}{l}\text { Autonomous: dissimi- } \\
\text { lar and uncoordinated } \\
\text { country systems }\end{array}$ & $\begin{array}{l}\text { No defined organisation or management nationally } \\
\text { or outside of an organisation (an individual organ- } \\
\text { isation has self-government) }\end{array}$ \\
\hline $\begin{array}{l}\text { Integrated: compat- } \\
\text { ible and co-ordinated } \\
\text { systems }\end{array}$ & $\begin{array}{l}\text { An integrated management system that aligns with a } \\
\text { company's strategic aims such as the intranet. }\end{array}$ \\
\hline
\end{tabular}

\section{Table 3: ICT based organisational strategies (after Frankovich, 1998).}

larger companies, when working on larger projects, prefer to have an intranet for the project, unless the contractor or client has the power to enforce joining their systems. Therefore, company and project configurations may be different, as evidenced here, which in turn affects the way in which individuals and project organisations communicate and thus perform. It is also common for construction companies to use electronic psychometric assessments on construction personnel to determine their personality traits and aptitudes. These tests are now managed via ICT through a company's intranet (Cascio, 1995). Cascio (1995) questions whether a true and valid measurement of one's abilities and traits can be obtained through a closed hard-system survey approach. This is because differing personal characteristics or traits are required in differing roles. The discussion with the company owners of the SME observed revealed all new employees are interviewed face to face and electronic means of judging a person's skills and traits will not be considered by these Directors in the future because of the importance of meeting people. The interviewees prefer the psychometric testing because of lack of time and the need to narrow down the applicants. This ICT configuration shows the disparity and fragmentation between the way project information is dealt with and communicated and employees are selected.

\section{Question 3: Distraction in construction organisations}

The academic debate on the effects of ICT in organisations is large, a factor that in itself indicates a degree of distraction caused by the use and potential use of technology for communication. This debate also indicates a need for an appropriate skill-set along with an understanding of purpose to avoid compromising project performance. Despite the size of the academic debate, it contains little empirical evidence that identifies particular factors that interfere with or distract from effective communication. Whilst some may be obvious, such as noise and social distractions from mobile devices, this study sought to move towards filling this gap, through observation and interview. During the observation of office practice, it was clear that understanding was affected by the way people wrote and read emails. In both cases, the perceived need for speedy communication encouraged by the potentially instantaneous nature of electronic means distracted people from reflecting on content. Messages were most likely to be written "off the cuff", often without reading over and understanding the matter and sometimes without a spell check. Occasionally these messages had to be rewritten or even recalled when the writer noticed errors after hitting the send button or further receiving of messages indicated conflicting understanding. Messages received were often skimmed when read and people checked their email in-boxes frequently whilst undertaking other tasks. This meant that the arrival of emails was a distraction from these other tasks. Electronic transfer created bureaucracy in the office when workers sent emails even though they were sharing the office and used emails instead of face to face meetings to discuss pertinent aspects of a project. It is acknowledged that communication without due reflection causes problems.

Frustration still occurs amongst teams when a response is not immediate or there is a break down. Video conferencing, however, allows for real-time communication and saves times with the need for minimal travelling (if there are no technical issues) but lack of presence of people inperson reduces trust as well as other practical issues (Bower et al, 2001) and the bigger picture is not easily distinguishable for example, it is easy to portray positivism in front of a camera yet behind the scenes more may be going on that is not being communicated and cannot be seen by the other parties thus limiting access into the real social environment (Williams et al, 2000; Bower et al, 2001). Therefore, the dynamic within teams is more vulnerable when communicating and collaborating virtually (Curseu et al, 2008) since the receiving and processing of communication lacks the 
additional physical cues provided by the in-person team approach.

Both interviewees identified incompatibility of software as the principal distraction from project performance. They felt it was most obvious when there are design issues and the architect, structural engineer and the steelwork fabricator have different packages. This causes frustration and usually results in the need for face to face communication - clearly this becomes a big problem when the team is working virtually. It has been suggested that providing appropriate communication has a positive effect (Cuddleback and Redden 2009, Dainty et al. (2006)) and is vital to the success of a construction project (Franks 1990). If it is evident that an understanding is lost during electronic communication, virtual teams have an additional problem of deciphering what appropriate communication is required if face to face contact is not possible (Verberg et al. 2013). It is not common practice for construction personnel to be specifically trained how to manage virtual communication and be a part of a virtual team nor the way in which to communicate. The interviewees selected people to be part of virtual teams if they felt they were appropriate for the project (not appropriate for virtual communication) and company owners agreed that if they won a project requiring virtual working that, due to the size of their company, they would require everyone participating but how they would go about this was unknown.

\section{Question 4: Cultural and Sex Difference}

ICT is used extensively as a social interpersonal tool, particularly amongst younger people (Business Matters, 2013). 'A business of tomorrow will inevitably use social media as a central communicators' tool' (Business Matters, 2013). As a result of the lack of social interaction due to use of ICT both outside of and in the workplace, we are now growing accustomed to overanxious communicators, this is particularly evident in European countries due to the over use of social and instant messaging (Pierce, 2009; Lenhart et al., 2005). It was identified during the observation by the owners of the company that there is 'unwillingness' by the younger employees to communicate synchronously speculating the reason could be that the employees are too apprehensive without ICT involvement. ICT reliance is the distraction in this case affecting the social performance of employees. A study on communication in the workplace by Business Matters (2013) determined that 'most workers have become so used to using indirect communication methods such as email and conference calls, they are less confident when communicating face to face' (Business Matters, 2013). $70 \%$ of personnel of all ages preferred to use some form of hard communication (mostly email) than face to face communication, even when communicating with colleagues in the same building (Business Matters, 2013). Over $50 \%$ claimed to be less confident socialising and communicating face to face due to their reliance on hard communication (mainly 'email, telephone and skype') (Business Matters, 2013). During the observation, ICT use was indistinguishable between females and males and older and younger workers due to automatic reaction from all. It was noticed that the younger workers tended to communicate with colleagues electronically rather than face to face probably because ICT is more prominent now than it's ever been and children are exposed to it instantaneously. Younger users in particular tend to respond more quickly to an electronic message or at least view it without an 'understanding' taking place. This was in evidence during the observation. Conversely, the interviewees maintained that there is a noticeable difference in the attitude towards the use of technology between the more experienced and younger generations. The more experienced employees do not resist the increasing use of technology but they do not always prefer this approach. Many of this more mature generation consider face to face, collaborative working is more effective "as you can see the whites of their eyes." The younger less experienced construction employees appear to embrace ICT. This reflects their confidence and the cultural shift away from face to face working. Markedly, a move away from, and desire for, face to face communication in construction is symptomatic of the popularity and development of ICT. Regardless of age and sex, it seems that, at present, some people prefer to communicate in-person whilst others, whether it be due to anxiousness or social inability, prefer to communicate via ICT within a project organisation.

Technology's effect on people today is not yet proven but some researchers have established that the internet for example is used more for socialising than face to face interaction (Sproull and Kiesler, 1991; Kraut et al, 1998; Flaherty et al, 1998;Bridges 1997). This increase in the use of the internet is associated with a decrease in family time and general social involvement (Kraut et al, 1998). It is obvious that the younger generation is more conscious of ICT due to their exposure to it from an earlier age. Based on Zacharatos et al's (2000) research on the transformational leadership development of youths, Day et al (2014) concluded that advances in leadership are fashioned from a juvenile age and influenced by 'parental modelling' 'but ongoing practice through day to day leadership activities is where the crux of development really resides' (p.80). During the observation, the owners revealed that the social skills of their younger em- 
ployees were not ideal for managing projects. They felt this was due to a lack of formal social skills indicated by an unwillingness to communicate in person and professionally. They were concerned that their employees would not go on to perform properly as managers or leaders. The importance of this premature learning and development is supported by Murphy and Johnson (2011) indicating that the recurrence of technologically gripped communicators is likely to create a 'new type' of leader or worker in the future of the construction industry.

Reichard and Johnson (2011, p.33) affirm that the self-development of a leader is 'a cost-effective way for organisations to develop leaders resulting [potentially] in a competitive edge'. This requires self-reflection (and awareness), engagement and open, transparent organisational support for self and skill development. Galli and Muller-Stewens (2012) termed this self-development 'social capital' whereby communication (and collaboration) is carried out within a social context. The laboratory research that was carried out on the information technology product Lotus Notes in 1999 to test its assistance on communication and collaboration confirmed that an understanding of the social environment in which the technology is being adopted is required foremost (Olesen and Myers, 1999). However, the replacement of traditional soft communication with ICT (and thus the loss of these traditional ideals) suggests difficultly judging the necessity and positioning of technology in a project organisation by newer generations. To illustrate this, as we move into the era of BIM (Building Information Modelling) technology with growing reliance on software there are already concerns that the people in-putting the information into the systems are not professionally qualified but are data in-putters i.e. technologically proficient people from the newer generation. As the software becomes more sophisticated and off site manufacturing becomes more common place the designers' software will talk to the subcontractors' software missing out the human element, which means that thinking and understanding becomes less and the entire way we communicate and collaborate becomes distracted. This can lead to major problems if there is not a clear and structured feedback mechanism to monitor and review the output of this data. The interviewees agreed that equally both the older and younger generations consider that electronic information transfer is convenient and do not consider sending an e-mail to someone on the project at $10 \mathrm{pm}$ is unreasonable. However, the main issue appears to be the message itself and the fact that with ICT "you do not know if it has been understood." Both generations consider there should be some protocols in place to allow for conformity of message sending thus aiding understanding. To develop a common understanding of what is to be achieved a strong interplay of human behaviour is required, not only to receive the message but to develop it into a workable solution. During this process there is a need to send the message and test the understanding which can be achieved through clearly identifying critical success factors (CSF's) at the beginning of the project.

The concept of the 'realm of understanding' is more likely when the sender and receiver attitudes, perceptions, behaviour, values and experience have common ground (Fill 2002), particularly where parties have a similar background using similar terminology and reporting systems. Personal preferences will vary the channels used, the format and content of the message and the frequency of interaction. The receiver has to decode the message successfully, but success is difficult to define. Feedback mechanisms are therefore essential to enable the sender to establish if the understanding is what was envisaged. Much of the literature published focuses on the company or the individual traits rather than the ages of the parties, cultural diversity or the technologies used. With the increased use of ICT and the different skill sets possessed by the generations using it, the frequency of reliance on ICT and the way in which communication (and collaboration) is dealt with varies. The primary research observed that the younger less experienced person is more likely to rely on electronic information transfer in the office but all ICT users are currently distracted from how they react, learn and thus manage correspondence. Additionally, it was observed that the inexperienced employees tended to be distracted from the situation or job at hand because of the use of ICT more regularly than the more experienced employees. This confirmed Dewatripont et al's (2005) observation that electronic message transfer in itself is a noise as it distracts the recipient from the work being done at the time, reduces 'mindfulness' and doesn't allow time for understanding and knowledge acquisition. Consequently, a question arises over whether in years to come, the social skills and traits currently exhibited by the more mature person will disappear if these skills are not passed on to younger professionals. More importantly, the impact of this on construction project performance is unknown.

\section{Question 5: Overuse of ICT or organisation?}

Ruiz-Mercader et al (2005) believe organisational performance cannot be improved through technology. They argue that self and organisational learning develops performance and ICT is indirect to this learning development (Ruiz-Mercader et al, 2005). Mohamed et al (2006) identify that ICT alone is not sufficient as human 
and organisational aspects are important parts of communication (and collaboration). The ICT within the workplace observed did not appear to have any organisational issues but the organisation of the team using the ICT displayed problems such as the reliance upon the information input and electronic transfer. Certain parts of ICT did not seem to be keeping pace with what people want to do since there was evident frustration with some ICT use and when using ICT to communicate externally, variance occurred due to differing ICT strategies being adopted between organisations. There is no uniform approach to ICT as it appears to be seen that Architects and designers develop visual programmes whilst other professionals use general ICT. This also varies with the size of the company so it is not surprising that systems vary with each company resulting in poor interaction between ICT and human interpretation.

Personal traits and skills (particularly of managers and leaders) were originally based on soft principles of communication so not only are new 'skills' required to adapt to ICT use in construction and ICT specific specialisms but the traditional traits and skills may be being lost due to the over- and/or misuse of ICT. Flyvbjerg, (2009) argues that the incompatibility of communication within project teams due to the inadequacies of communication between individuals is exacerbated by team diversity and the use of ICT. This confirms the findings from the primary study.

\section{Findings}

A figure displaying the contribution of knowledge was developed to illustrate the findings of the literature review and primary research for each question and is contained in Figure 3 below. This figure shows the progressively negative impacts of ICT on communication moving vertically whist

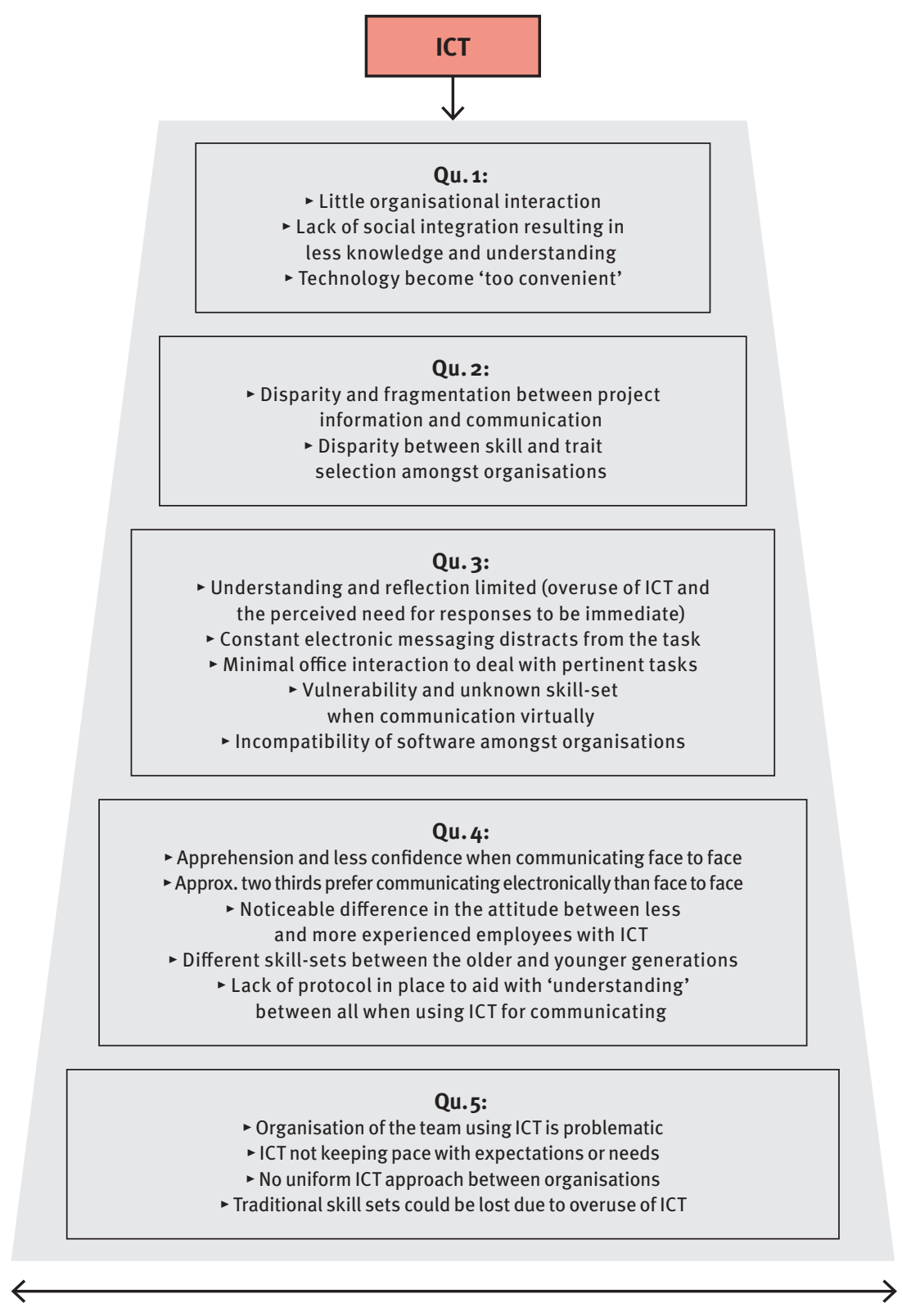

Figure 3: Contribution to Knowledge

the breadth of the model elements notionally represent an increasing impact on construction project performance as the issues move from specific to generic.

This model shows how issues created from the main use of ICT for communication in construction widen as ICT develops and interpersonal communication decreases.

\section{Conclusions}

Question 1: The preferred and most appropriate approach to communica- tion is considered to be synchronous, mainly face to face but in actual practice this seems to not be the case. In practice, most people use or rely on technology (but this varies depending on the complexity of the issue). The overuse and misuse of technology within the office environment may reduce employees awareness of what is happening in the workplace. Managers and leaders are under pressure to manage and direct teams with a tendency to replace face to face communication with technology in 
order to provide monitored efficiency. Generally it's accepted that electronic information transfer is beneficial for storing information but prioritising what is urgent and important is difficult. The other issue is that the use of email and instant messaging does not ensure that the recipient has understood the message; this then limits the reaction (and the quality of it). The speed of communication enables greater quantities of information to be transferred leading to potential for information overload, this is often cited as a reason for errors and misunderstandings.

Question 2: An intranet organisation was the preferred communication option for all parties in the research sample and this may be due to the type of work being undertaken. However the difference in size of companies within the industry, technology awareness and compatibility and skill set influence the effectiveness of this approach with smaller companies housing a shared hard drive and larger companies adopting an extranet.

Question 3: There is a need to develop communication technology that uses pictorial messages rather than just text. Geographical distance between parties supports the use of electronic communication. Because of ease of sending messages, senders can easily adopt a scatter-gun approach with long circulation lists rather than a more directed approach. However, soft interaction is considered to be more appropriate when there is anything other than mundane communication. Therefore a high level of soft interaction is needed when there are problems and issues to be resolved. Flexible working creates a virtual team even within the same project regardless of distance, this can isolate the parties creating a lack of team work and misunderstanding of the project goals. A construction project organisation houses the potential for cultural disparity with employees who lack full awareness of and concentration on what is taking place due to the disturbance of using technology and the distraction it causes.

The observation showed that ICT created 'anticipation' which is a distraction (or noise) since the receptor sense to technology alerts people and captures their attention. The construction industry relies on the effective flow of information received; analysed, converted, priced and so on and deep thinking should take place throughout the process to ensure understanding occurs. ICT clearly became a distraction due to the lack of focus on thinking and what should be dealt with and more on the handling of mails, instant messaging and so on. There were episodes when ICT also distracted from face to face communication and conversation which had the potential to affect the company performance.

Question 4: Younger users are generally more technically adept when using electronic communication but there is a discrepancy in understanding the content and the impact of the way in which they send the message. Moreover, leadership and management roles may change in the future as skills and traits change to adapt to communication that is more ICT based which will resultantly affect construction as a whole. The dependence on ICT for social networking and instant messaging from a young age has the potential to interfere with and affect people's social skills and social awareness.

Question 5: The organisation of ICT does not appear to be a problem but the organisation of people using it does. ICT has shown to be over utilised by many within the construction industry. ICT is obviously the way forward but there is a need to use the appropriate methods and approaches. In terms of making organisational improvements, as well as retaining traditional skills and traits, a new skill set is required so that the sender and receiver appreciate how messages can be mutually understood without the need for intensive reinterpretation when things go wrong. 


\section{References}

Appelbaum, S.H., Karasek, R., Lapointe, F. and Quelch, K., 2015. Employee empowerment: factors affecting the consequent success or failure (Part II). Ind and Commercial Training, 47 (1), 23-30.

Arvey, R, \& Murphy, K 1998, 'Performance evaluation in work settings', Annual Review Of Psychology, 49, 1, p.141, Academic Search Complete, EBSCOhost, viewed 4 June 2015.

Atkin C K, Donohue W A, Johnson D J, Johnson S, 1994 Differences Between Formal and Informal Communication Channels. The Journal of Business Communication, 31 (2), 111-122.

Austin S A, Baldwin A N, J L Steele J L (2002) Improving building design through integrated planning and control Engineering Construction and Architectural Management, 9 (3) (2002), pp. 249-258.

Baiden, B.K., Price, A.D.F. and Dainty, A.R.J., (2006). The extent of team integration within construction projects. International Journal of Project Management, 24(1), pp. 13-23.

Ballard, G., and Howell, G. A., 2003. An Update on Last Planner. [online] Lean construction Institute. Available at: http://www.leanconstruction.dk/media/16974/An\%2oUpdate\%20 on\%2oLast\%2oPlanner.pdf

Barratt, M. (2004), “Understanding the meaning of collaboration in the supply chain", Supply Chain Management: An International Journal, Vol. 9 No. 1, pp. $30 \square 42$.

Beach, R., Webster, M.and Campbell, K. M. (2005). "An evaluation of partnership development in the construction industry." Int. J. Proj. Manage., 238, 611-621.

Belbin, R.M., 1999. Changing the Way We Work. Oxford: Butterworth-Heinemann.

Blume, B.d., Baldwin, T.t. and Ryan, K.c., 2013. Communication Apprehension: A Barrier to Students' Leadership, Adaptability, and Multicultural Appreciation. Academy of Management Learning \& Education,12 (2), 158-172.

Bouchlaghem, D., Shang, H., Whyte, J., \& Ganah, A. (2005). Visualisation in architecture, engineering and construction (AEC). Automation in construction, 14(3), 287-295.

Bower, D.J., Hinks, J., Wright, H., Hardcastle, C. and Cuckow, H., 2001. ICTs, videoconferencing and the construction industry: opportunity or threat? Construction Innovation (Sage Publications, Ltd.), 1 (2), 129-144.

Bresnen, M., and Marshall, N. 2000 "Building partnerships: Case studies of client contractor collaboration in the UK construction industry."Constr. Manage. Econom., 18, 819-832.
Bridges, A.H., 1997. Implications of the internet for the construction industry. Automation in Construction, 6 (1), 45-49.

Bryman, A., 2008. Social research methods. 3rd ed.. ed. Oxford ; New York: Oxford ; New York: Oxford University Press.

Cain, T., C., (2004) Profitable partnering for lean Construction .Blackwell Publishing, UK: Oxford.

Cascio, W., 1995. Whither industrial and organizational psychology a changing world of work? American Psychologist, 50 (11), 928939.

Chan, A. P., \& Chan, A. P. (2004). Key performance indicators for measuring construction success. Benchmarking: an international journal, 11(2), 203-221.

Chan, D. W., \& Kumaraswamy, M. M. (1997). A comparative study of causes of time overruns in Hong Kong construction projects. International Journal of Project Management, 15(1), 55-63.

Chan, E. H., \& Tse, R. Y. (2003). Cultural considerations in international construction contracts. Journal of Construction Engineering and Management, 129(4), 375-381.

Chinyio, E and Akintoye, A (2008) Practical approaches for engaging stakeholders: Findings

Chinyo and Omolaiye (2010) "Construction stakeholder management”, London Blackwell.

Cohen, J B. and Basu K (1987), "Alternative Models of Categorization: Toward a Contingent Processing Framework," Journal of Consumer Research, 13 (March), 455-472.

Connolly, E., \& Fox, K. J. (2006). The impact of high $\square$ tech capital on productivity: evidence from Australia. Economic Inquiry, 44(1), 50-68.

Crotty, R. (2012) The impact of Building Information Modelling: transforming construction. Spon Press, Oxon, UK

Cuddeback, K., and Redden, P., 2009. Building Connections: A Clinical Operations View of Activation Planning. Herd-Health Environments Research \& Design Journal; Herd-Health Env. Res.Des.J., 2 (4), 113-126.

Dainty, A. Moore, D., and Michael, M. (2006) Communication in Construction: Theory and Practice. Taylor and Francis, Oxon.

Daniel, E I, Pasquire, C and Dickens, G (2014b) Social perspective of planning in construction: The UK experience In: Raiden, A B and Aboagye-Nimo, E (Eds) Procs 3oth Annual ARCOM Conference, 1-3 September 2014, Portsmouth, UK, Association of Researchers in construction Management, 1355- 1365.

Dane, E., 2011. Paying Attention to Mindfulness and Its Effects on Task Performance in the
Workplace. Journal of Management, 37 (4), 997-1018.

Danziger, J.N., and Kraemer, K.L., 1990. The impacts of computer technology the worklife of information workers. Social Science Computer Review, 8 (4), 592-613.

Davis, P., \& Love, P. (2011). Alliance contracting: adding value through relationship development. Engineering, Construction and Architectural Management, 18(5), 444-461.

Davis, D. D., Mihalescz, M., Bryant, J. L., Tedrow, L., Liu, Y., \& Say, R. (2003). Leadership in global virtual teams. Paper presented at the meeting of the Society for Industrial and Organizational Psychology, Orlando, Florida.

Day, D.V., 2000. Leadership development: A review in context. The Leadership Quarterly, 11 (4), 581-613.

Day, D.V., Fleenor, J.W., Atwater, L.E., Sturm, R.E. and McKee, R.A., 2014. Advances in leader and leadership development: A review of 25 years of research and theory. The Leadership Quarterly, 25 (1), 63-82.

De G, A. P. (1988). ‘Planning as learning'. Harvard Business Review, Mar.-Apr.,70-4.

Denning, S., 2011. The reinvention of management. Strategy \& Leadership, 39 (2), 9-17.

Denning, S., 2013. Ten drivers of radical management in the "creative economy". Strategy \& Leadership, 41 (6), 18-30.

Dewatripont, M., and Tirole, J., 2005. Modes of Communication. Journal of Political Econo$m y, 113$ (6), 1217-1238.

Egan, J. (1998). Rethinking construction: The report of the construction task force. DETR, London.

Egan, J. (2002). Accelerating change: a report by the strategic forum for construction. Rethinking Construction. SF f. Construction, London.

Emmitt, S., (2010). Managing Interdisciplinary Projects. Oxon: Taylor and Francis.

Emmitt, S., 2003. Construction communication. Oxford: Oxford: Blackwell Science.

Evbuomwan, N.F.O and C.J. Anumba, C.J (1998)An integrated framework for concurrent life-cycle design and construction. Adv. Eng. Software, 29 (7-9) (1998), pp. 587-597

Fellows, R., 1948-, 2008. Research methods for construction electronic resource]. 3rd ed.. ed. Oxford: Oxford : Wiley-Blackwell.

Fellows, R, \& Liu, A 2012, 'Managing organisational interfaces in engineering construction projects: addressing fragmentation and boundary issues across multiple interfaces'. Construction Management \& Economics, 30, 8, pp. 653-671, Business Source Complete, 
EBSCOhost, viewed 23 April 2015.

Flaherty, L.M., Pearce, K.J. and Rubin, R.B., 1998. Internet and face $\square$ to $\square$ face communication: Not functional alternatives. Communication Quarterly, 46 (3), 250-268.

Flyvbjerg, B. (2009) Survival of the unfittest: why the worst infrastructure gets built and what we can do about it. Oxford Review of Economic Policy, 25(3), 344-67.

Fong, P. S. W., and Lung, B. W. C. 2007 . "Interorganizational team work in the construction industry." J. Constr. Eng. Manage., 1332, 157-168.

Formoso, C.T. and Moura, C.B. (2009) "Evaluation of the impact of the last planner system on the performance of construction projects", Proceedings ofthe17thAnnual Conference of International Group for Lean Construction, Taiwan, pp. 153-164, 2009.

Franks, J. (1990) Building Procurement Systems: a guide to building project management., 2nd Edition; CIOB, Ascot.

Frankovich, J. (1998) 'The techno-world'. Mastering Global Business. London: PriceWaterhouseCoopers/Financial Times/Pitman.

Frederick, W. C., 1998. Creatures, corporations, communities, chaos, complexity: A naturological view of the corporate social role. Business Society, 37 (4), 358-389.

Freeman, R. E., 1984. Strategic management. A stakeholder approach. Boston, MA: Pitman.

from the UK. Construction Management and Economics, 26(4), 591-599.

Freeman, S.A., Littlejohn, S.W. and Pearce, W.B., 1992. Communication and moral conflict. Western Journal of Communication, 56 (4), 311-329.

Fulford, R., \& Standing, C. (2014). Construction industry productivity and the potential for collaborative practice. International Journal of Project Management, 32(2), 315-326.

Furst, S., Blackburn, R. and Rosen, B., 1999. Virtual team effectiveness: a proposed research agenda. Information Systems Journal; Inf. Syst.J., 9 (4), 249-269.

Galli, E., and Muller-Stewens, G., 2012. How to build social capital with leadership development: Lessons from an explorative case study of a multibusiness firm. Leadership Quarterly; Leadersh.Q., 23 (1), 176-201.

Goh, S. C. and Richards, G.( 1997). Benchmarking the learning capability of organisations. European Management Journal 1997, 15 (5): 575-583.

Gorse, C., and Emmitt, S., 2007. Communication behaviour during management and design team meetings: a comparison of group inter- action. Construction Management and Economics, 25 (11), 1195.

Gray, David E. (David Edward),1952- author, 2013. Doing research in the real world. 3rd edition.. ed.

Grigg NS. New paradigm for coordination in water industry. J Water

Gunder, Michael. "Planning as the ideology of (neoliberal) space." Planning Theory 9.4 (2010): 298-314.

Hayes, P., Herschel, R., (1996). Organizational Communication: Empowerment in a Technological Society. Indiana University: Indiana.

Hayek, F. A. (1945). The use of knowledge in society. The American economic review, 519-530.

Healey, P. (2003). Collaborative planning in perspective. Planning theory, 2(2), 101-123.

http://rem-main.rem.sfu.ca/theses/MortonCedar_2009_MRM482.pdf [Accessed : 19/11/2014]

Hoch, J.E., and Kozlowski, S.W.J., 2014. Leading virtual teams: Hierarchical leadership, structural supports, and shared team leadership. Journal of Applied Psychology, 99 (3), 390-403.

Igbaria, M., 1999. The driving forces in the virtual society. Communications of the ACM; Commun. ACM, 42 (12), 64-70.

Jaafari, A., \& Manivong, K. (1999). The need for life $\square$ cycle integration of project processes. Engineering Construction and Architectural Management, 6(3), 235-255.

T. Jackson, J. (2014). Planning for Social Inclusion? What Planners from Glasgow, Melbourne and Toronto Say. International Planning Studies, 19(1), 45-76.

Jamal, B. T. and Getz, D. (1995). Collaboration theory and community tourism planning. "Annals of Tourism Research”, 22(1), 186-204.

Jamal, T. B., \& Getz, D. (1995). Collaboration theory and community tourism planning. Annals of tourism research, 22(1), 186-204.

Jarvenpaa, S., and Leidner, D., 1999. Communication and trust in global virtual teams. Organization Science; Organ Sci., 10 (6), 791-815.

Jha, K. N., \& Iyer, K. C. (2006). Critical determinants of project coordination. International Journal of Project Management, 24(4), 314322.

Jorgensen, B. (2004). Individual and organisational learning: a model for reform for public organisations. foresight, 6(2), 91-103.

Kalay, Y. E. (1999). The future of CAAD: From computer-aided design to Computer-aided collaboration. In Computers in Building (pp. 13-30). Springer US

Kalsaas, B. T. (2012). The last planner system style of planning: its basis in learning theory. Journal of Engineering, Project, and Production Management, 2(2), 88-100.

Kastalli I. V and Neely, A. (2013). Collaborate to innovate. How business ecosystems unleash business Value [online]. The Cambridge Service Alliance. Available at : http://www.ifm. eng.cam.ac.uk/uploads/Resources/Collaborate_to_Innovate_-_ecosystems_-_final.pdf

Kayworth, T., and Leidner, D., 2000. The global virtual manager: a prescription for success. European Management Journal, 18 (2), 183-194.

Kees, N., and Whichard, J., (2006). The manager as facilitator. Praeger Publishers: USA.

Kolb, D. A. (1984). Experiential learning: Experience as the source of learning and development (Vol. 1). Englewood Cliffs, NJ: PrenticeHall.

Kirkman, B. L., Rosen, B., Tesluk, P. E., \& Gibson, C. B. (2004). The impact of team empowerment on virtual team performance: The moderating role of face-to-face interaction. Academy of Management Journal, 47, 175-192.

Konradt, U., \& Hertel, G. (2002). Management virtueller Teams-von der Telearbeit zum virtuellen Unternehmen [Managing virtual teams]. Weinheim7 Beltz Verlag.

Koryak, O., Mole, K.F., Lockett, A., Hayton, J.C., Ucbasaran, D. and Hodgkinson, G.P., 2015. Entrepreneurial leadership, capabilities and firm growth. International Small Business Journal, 33 (1), 89-105.

Kraut, R., Patterson, M., Lundmark, V., Kiesler, S., Mukopadhyay, T. and Scherlis, W., 1998. Internet paradox - A social technology that reduces social involvement and psychological well-being? American Psychologist; Am.Psychol., 53 (9), 1017-1031.

LaFasto, F. and Larson, C.,(2001) When Teams Work Best. Sage Publications: California.

Lenhart, A., Maddenn, M. and Hitlin, P., 2005. Teens and technology: Youth are leading the transition to a fully wired and mobile nation.

Lester, A., (2007). Project Management, Planning and Control (Fifth Edition) Managing Engineering, Construction and Manufacturing Projects to PMI, APM and BSI Standards. Elsevier. p293 -295 .

Leung, M. and Olomolaiye, P. (2010). Risk and construction stakeholder management. In: Chinyio, E. and Olomolaiye, P. (Eds.) "Construction Stakeholder Management”, John Wiley \& Sons Ltd, United Kingdom, 75 - 98.

Leung, M. Y., \& Olomolaiye, P. (2009). Risk and construction stakeholder management. Construction stakeholder management, Chichester, UK, 75-98. 
Lipnack J, Stamps J. (2000) Virtual teams. 2nd ed. New York: Wiley.

Liu, Y. (2009), Critical Factors for Managing Project Team Communication at the construction stage. PhD Thesis. www.lib.polyu.edu.hk ISBN: 9781109493122

Lonngren, H.-M., Rosenkranz, C. \& Kolbe, H. (2010) Aggregated construction supply chains: success factors in implementation of strategic partnerships. Supply Chain Management: An International Journal, 15, 404 - 411.

Malone, T. W., \& Crowston, K. (1994). The interdisciplinary study of coordination. ACM Computing Surveys (CSUR), 26(1), 87-119.

Manowong, E and Ogunlana, S (2010) Strategies and tactics for managing construction stakeholders. In: E. Chinyio and P. Olomolaiye, (eds.) "Construction Stakeholder Management". Chichester: Wiley- Blackwell.

Mattessich, P. W., \& Monsey, B. R. (1992). Collaboration: what makes it work. A review of research literature on factors influencing successful collaboration. Amherst H. Wilder Foundation, 919 Lafond, St. Paul, MN 55104.

Mattessich, P. W., \& Monsey, B. R. (1992). Collaboration: what makes it work. A review of research literature on factors influencing successful collaboration. Amherst H. Wilder Foundation, 919 Lafond, St. Paul, MN 55104.

Maznevski, M., and Chudoba, K., 2000. Bridging space over time: Global virtual team dynamics and effectiveness. Organization Science; Organ Sci., 11 (5), 473-492.

McGraw Hill Construction Smart Market Report, (2013). Lean Construction: Leveraging Collaboration and Advanced Practice to increase Project Efficiency[Online]. Available at: http:// bradleybim.com/2013/11/24/download-mcgrawhill-lean-construction-bim-report-2013/

Mohamed, M., Stankosky, M. and Murray, A., 2006. Knowledge management and information technology: can they work in perfect harmony? Journal of Knowledge Management, 10 (3), 103-116.

Morton, C.A.J, (2009). Evaluating collaborative planning: A case study of the morice land and resource management plan[ online]. Master research project thesis subject to Simon Fraser University. Available at :http://www. silverhillinstitute.ca/pdf/cedar_morton_final_paper.pdf

Mossman, A (2014) Last Planner: collaborative conversations for predictable design and construction [online]. Available at: http://www. academia.edu/1267793/Last_Planner_collaborative_conversations_for_predictable_ design_and_construction_delivery
Naoum, S.G.(., 2013. Dissertation research \& writing for construction students electronic resource]. 3rd ed.. ed. London: London : Routledge.

Newcombe, R., Langford, D., and Fellows, R., (1990). Construction Management 1-Organisation Systems. Mitchell Publishing Company Ltd: London.

Newcombe, R. (2003). From client to project stakeholders: a stakeholder mapping approach. Construction Management and Economics, 21(8), 841-848.

Notari, M., Baumgartner, A. and Herzog, W., 2014. Social skills as predictors of communication, performance and quality of collaboration in project-based learning. Journal of Computer Assisted Learning, 30 (2), 132-147.

O’Brien, W, Fischer, M, \& Jucker, J 1995, 'An economic view of project coordination', Construction Management \& Economics, 13, 5, p. 393, Business Source Complete, EBSCOhost, viewed 24 September 2014.

O‘brien, W. J., Fischer, M. A., \& Jucker, J. V. (1995). An economic view of project coordination. Construction Management and Economics, 13(5), 393-400.

Olander, S. (2007). Stakeholder impact analysis in construction project management. Construction Management and Economics, 25(3), 277-287.

Olesen, K., and Myers, M.D., 1999. Trying to improve communication and collaboration with information technology; An action research project which failed. Information Technology \& People, 12 (4), 317-332.

Oliva, C.A. \& Granja, A.D. 2013, 'An Investigation Into Collaborative Practices in Social Housing Projects as a Precondition for Target Value Design Adoption' In:, Formoso, C.T. \& Tzortzopoulos, P., 21th Annual Conference of the International Group for Lean Construction. Fortaleza, Brazil, 31-2 Aug 2013. pp 429-437

Parker, C., 2000. Performance measurement. Work Study, 49 (2), 63-66.

Parker, H. W. (1980) Communication: key to productive construction. Issues in Engineering, ASCE, 106 (El3): 173-180.

Peters, L.M., and Manz, C.C., 2007. Identifying antecedents of virtual team collaboration. Team Performance Management, 13 (3), 117-129.

Petru L. Curseu, René Schalk, Inge Wessel, (2008) "How do virtual teams process information? A literature review and implications for management”, Journal of Managerial Psychology, Vol. 23 Iss: 6, pp. $628-652$.

Pierce, T., 2009. Social anxiety and technology: Face-to-face communication versus techno- logical communication among teens. Computers in Human Behavior, 25 (6), 1367-1372.

Pulakos, Elaine D., Rose A. Mueller-Hanson, and Johnathan K. Nelson. "Adaptive Performance and Trainability as Criteria in Selection Research." Oxford Handbooks Online. 2012-11-21. Oxford University Press. Date of access 10 Mar. 2015, 〈http://www. oxfordhandbooks.com/view/10.1093/oxfordhb/9780199732579.001.0001/oxfordhb9780199732579-e-26〉.

Rahman, M. M., \& Kumaraswamy, M. M. (2005). Relational selection for collaborative working arrangements. Journal of Construction Engineering and Management, 131(10), 1087-1098. Resource Plan Manage, ASCE 1993;119(5):572-87. Reichard, R., and Johnson, S., 2011. Leader selfdevelopment as organizational strategy. Leadership Quarterly; Leadersh.Q., 22 (1), 33-42.

Ruiz-Mercader, J., Meroño-Cerdan, A.L. and Sabater-Sánchez, R., 2006. Information technology and learning: Their relationship and impact on organisational performance in small businesses. International Journal of Information Management, 26 (1), 16-29.

Sahay, B. S. (2003). Understanding trust in supply chain relationships. Industrial Management \& Data Systems, 103 (8), 553-563.

Samudio, M.; Alves, T.C.L.; Chambers, D. (2011). "Employing the principle of "going and seeing" to construction." Lean Construction Journal IGLC Special Issue 2011, pp 41-53. Available at www.leanconstructionjournal.org.

Schrage, M. (1990), Shared Minds: The New Technologies of Collaboration, Random House, New York, NY.

Scott, M. (2006). Wembley costs soar towards f1bn. [Online]. The Guardian Newspaper 24/11/2006. Available : http://www.theguardian.com/football/2006/feb/24/newsstory.sport2

Seifert, C., and Yukl, G., 2010. Effects of repeated multi-source feedback on the influence behaviour and effectiveness of managers: A field experiment. Leadership Quarterly; Leadersh.Q., 21 (5), 856-866.

Sexton, M. and Barrett, P. (2004), "The role of technology transfer in innovation within small construction firms", Engineering, Construction and Architectural Management, Vol. 11 No. 5, pp. $342 \square 8$.

Shannon, Claude E. \& Warren Weaver (1949): A Mathematical Model of Communication. Urbana, IL: University of Illinois Press.

Shelbourn, M, Sheriff, A., Bouchlagham, D., ElHamalawa and Yeomans, S., (2012). Collaboration Key concepts. In Bouchlaghem, Collab- 
orative working in construction. London; New York: Spon Press.

Shelbourn, M., Bouchlaghem, D., Koseoglu, 0.0. and Erdogan, B. (2005), "Collaborative working and its effect on the AEC organisation", Proceedings of the International Conference on Computing in Civil Engineering, Cancun, Mexico, $11 \square 15$ July

Shohet, I., and Frydman, S., 2003. Communication patterns in construction at construction manager level. Journal of Construction Engineering and Management-Asce; J.Constr.Eng. Manage.-ASCE, 129 (5), 570-577.

Skinnarland, S. (2013). Use of progression planning tools in developing collaborative main contractor-subcontractor relationships in Norway (Doctoral dissertation, Heriot-Watt University).

Slocum, J, A., (2008). Fundamentals of Organizational Behavior. International Ed. South Western College: US.

Smith, J., \& Love, P. E. (2004). Stakeholder management during project inception: strategic needs analysis. Journal of architectural engineering, 10(1), 22-33.

Sproull, K., Kiesler, S., 1991. Group decision making and communication technology. Journal of Organisational Behaviour and Human Design Processes, 52 (1), 96-123.

Starik, M., 1995. Should trees have managerial standing? Toward stakeholder status for nonhuman nature. Journal of Business Ethics, 14 (3), 207-217.

Stephens, K.L., Wilson, O.D. and Skitmore, M.R. (1999), “Construction project partnering: two case studies", in Bowen, P.A. and Hindle, R.D. (Eds), Proceedings The International and Council for Building Research Studies and Documentation (CIB) W55 W65 Joint Triennial Symposium, “Customer Satisfaction: a Focus for Research and Practice”, Cape Town, South Africa, pp. 229 37.

Thamhain, H., "Changing Dynamics of Team Leadership in Global Project Environments," American Journal of Industrial and Business Management, Vol. 3 No. 2, 2013, pp. 146-156. doi: 10.4236/ajibm.2013.32020.

The Cambridge Business Dictionary, (2014). Meaning of collaboration [online]. Available at : http://dictionary.cambridge.org/dictionary/ business-english/collaboration [Accessed: 19/11/2014]

Townsend, A. M., DeMarie, S. M., \& Hendrickson, A. R. (1998). Virtual teams: Technology and the workplace of the future. Academy of Management Executive, 12, 17-29.

Tuli, F., 2010.The Basis of Distinction Between
Qualitative and Quantitative Research in Social Science: Reflection on Ontological, Epistemological and Methodological Perspectives. Ethiopian Journal of Sciences, 6(1), pp. 97-108. Verburg, R.M., Bosch-Sijtsema, P., Vartiainen, M. (2013). Getting it done: Critical success factors for project managers in virtual work settings. International Journal of Project Management. Vol. 31. Pg. 68-79.

Verburg, R.M., Bosch-Sijtsema, P. and Vartiainen, M., 2013. Getting it done: Critical success factors for project managers in virtual work settings. International Journal of Project Management; Int.J.Proj.Manag., 31 (1), 68-79.

Vyse, S., (2001). Fusion: A New Approach to Working. GlaxoWellcome, London

Wallbaum, H., Silva, L., du Plessis, C., Cole, R. J., Hoballah, A., \& Krank, S. (2010). Motivating stakeholders to deliver change. In 3rd International Holcim Forum for Sustainable Construction, 'Re-inventing Construction', Mexico City, Mexico.

Williams, R., Slack, R. and Stewart, J. 2000: Social Learning in Multimedia. Final Report EC Targeted

Socio-Economic Research Project : 4141 PL951003, January. Available from R.Williams@ed.ac.uk

Wilkinson, P. (2005). Construction collaboration technologies: the extranet evolution. Taylor \& Francis.

Wolstenholme, A., Austin, S.A., Bairstow, M., Blumenthal, A., Lorimer, J., McGuckin, S., Rhys Jones, S., Ward, D., Whysall, D. and Le Grand, Z., 2009. Never waste a good crisis: a review of progress since Rethinking Construction and thoughts for our future.

Wu, F., Yeniyurt, S., Kim, D. and Cavusgil, S., 2006. The impact of information technology on supply chain capabilities and firm performance: A resource-based view. Industrial Marketing Management; Ind.Mark.Manage., 35 (4), 493504.

Xue, X., Shen, Q., \& Ren, Z. (2010). Critical review of collaborative working in construction projects: business environment and human behaviors. Journal of Management in Engineering, 26(4), 196-208.

Yager, S.E., 1997. Everything's coming up virtual. Crossroads, 4 (1), 20-24.

Yeomans, S.G., Bouchlaghem, N.M. and El-hamalawi, A., 2006. An evaluation of current collaborative prototyping practices within the AEC industry. Automation in Construction, 15(2), pp. 139-149.

Zacharatos, A., Barling, J. and Kelloway, E., 2000. Development and effects of transformational leadership in adolescents. Leadership Quarterly; Leadersh.Q., 11 (2), 211-226. 